\title{
ЕКОЛОГІЯ
}

UDC 502.52(292.485):631.153.3(477)

Sergiy Petrovych Sonko,

Doctor of Sciences (Geography), Professor,

Department of ecology and safety of vital functions, Uman National University of Horticulture,

Instytutska str., 1, Uman, Cherkasy region, 20300, Ukraine, e-mail: sp.sonko@gmail.com, https://orcid.org/0000-0002-7080-9564;

Nadiya Vasylivna Maksymenko,

$\mathrm{PhD}$ (Geography), Associate Professor, Department of Monitoring and Nature Management,

V. N. Karazin Kharkiv National University, Svobody sq., 6, Kharkiv, 61022, Ukraine, e-mail: nadezdav08@gmail.com, https://orcid.org/0000-0002-7921-9990;

Vilina Anatoliivna Peresadko,

Doctor of Sciences (Geography), Professor,

Department of Physical Geography and Cartography, V. N. Karazin Kharkiv National University,

Svobody sq., 4, Kharkiv, 61022, Ukraine,

e-mail: vilinaperesadko@gmail.com, https://orcid.org/0000-0002-2439-2788;

Iryna Prokhorivna Sukhanova,

$\mathrm{PhD}$ (Biology), Associate Professor, Department of ecology and safety of vital functions,

Uman National University of Horticulture, e-mail: sukhanoffaira@gmail.com,

Olga Volodymyrivna Vasylenko,

$\mathrm{PhD}$ (Agrarian Sciences), Associate Professor, Department of ecology and safety of vital functions, Uman National University of Horticulture, e-mail: vsolga05@gmail.com,

Olga Volodymyrivna Nikitina,

$\mathrm{PhD}$ (Agrarian Sciences), Associate Professor, Department of ecology and safety of vital functions,

Uman National University of Horticulture, e-mail: sp.sonko@gmail.com

\section{CONCEPT OF ENVIRONMENTALLY PROTECTIVE FARMING FOR THE FOREST-STEPPE ZONE*}

С.П. Сонько, Н.В. Максименко, В.А. Пересадько, І.П. Суханова, О.В. Василенко, О.В. Нікітіна. КОНЦЕПЦИЯ ЕКОЛОГІЧНО-ОЩАДЛИВОГО ЗЕМЛЕРОБСТВА ДЛЯ ЛІСОСТЕПОВӦ̈ ЗОНИ УКРАЇНИ. У статті акцентовано увагу на тому, що сільське господарство є найближчою до природних ландшафтів галуззю матеріально-енергетичних відносин. Тому основним завданням агроекології є пошук форм управління (спеціалізаиії), щчо не перевищуватиме природних можливостей певної території. Обтрунтовано, щзо найкраще управління природокористуванням на агроландшафтному рівні може бути реалізоване лише в разі повної визначеності земельної власності, а також за наявності невеликих площ у фермерів, які відповідатимуть низовим рівням ландшафтної структури. За таких умов фермер може піклуватися про підтримку природної родючості землі. Крім того, визначена власність на землю (а не оренду) змусить селянина сформувати спеціалізацію, щзоб максимально прачювати на самозабезпечення. За таких умов відродження худоби як гарантія підтримки природної родючості трунту - ие лише питання часу.

Авторська конщепиія, адаптована до умов лісостепу України, складається з серійних блоків дослідження: "Екологічний моніторинг агроландшафтних компонентів"; "Екологічна конверсія агроландшафтів"; "Ландшафтно-екологічне планування". Головна мета цієї Концепиії - не сфокусуватися на великих агрохолдингах, а на фермерських фермах.

Досвід проведення промислової типології сільського господарства в регіонах лісостепової зони України дає підстави вважати, що сучасна спеціалізація не тільки не є оптимальною в плані відповідності природним умовам, а й у багатьох випадках є руйнівною для трунтів. Тому оиінка впливу на навколишне середовище кожного виду сільського господарства, в першу чергу в лісостепу, а згодом і по всій території України, може бути аналогічною сучасній "електронній деклараиії" $i$ допомогти розробити стратегію екологічно раціональне управління сільським господарством. Розроблені технологічні методи екологічного перетворення (вермикультури, біодинаміка та ін.) адаптовані до умов лісостепу України та допоможуть власникам селянських та сільськогосподарських підприємств реалізовувати ияю стратегію на практиці.

Ключові слова: агроландшафти, типологія сільського господарства, конверсія, екологічно толерантне землеробство, ландшафтно-екологычне планування.

С. П. Сонько, Н. В. Максименко, В. А. Пересадько, И. П. Суханова, О. В. Василенко, О.В. Никитина. КОНЦЕПЦИЯ ЭКОЛОГИЧЕСКИ БЕРЕЖЛИВОГО ЗЕМЛЕДЕЛИЯ ДЛЯ ЛЕСОСТЕПНОЙ ЗОНЫ. В статье акиентировано внимание на том, что сельское хозяйство является ближайшей к природным ландшафтам отраслью материально-энергетических отношений. Поэтому основной задачей агроэкологии является поиск форм управления (специализации), которое не будет превышать природных возможностей определенной территории. Обосновано, что лучшее управление природопользовани-

(C) Son 'ko S. P., Maksymenko N. V., Peresadko V. A., Sukhanova I. P., Vasilenko O. V., Nikitina O. V. 
ем на агроландшафтном уровне может быть реализовано только в случае полной определенности земельной собственности, а также при наличии небольших площадей у фермеров, которые будут отвечать низовым уровням ландшафтной структуры. При таких условиях фермер может заботиться о поддержании естественного плодородия земли. Кроме того, определенная собственность на землю (а не аренду) заставит крестьянина сформировать специализацию, чтобы максимально работать на самообеспечение. При таких условиях возрождение скота как гарантия поддержки естественного плодородия почвы - это лишь вопрос времени.

Авторская кониепция, адаптированная к условиям лесостепи Украины, состоит из серийных блоков исследования: "Экологический мониторинг агроландшафтных компонентов"; "Экологическая конверсия агроландшафтов"; "Ландшафтно-экологическое планирование". Главная иель этой Концепџии - не сфокусироваться на крупных агрохолдингах, а на фермерских хозяйствах.

Опыт проведения промышленной типологии сельского хозяйства в регионах лесостепной зоны Украины дает основания считать, что современная специализачия не только не является оптимальной в плане соответствия природным условиям, но и во многих случаях является разрушительной для почв. Поэтому оченка воздействия на окружаюшую среду каждого вида сельского хозяйства, в первую очередь в лесостепи, а затем и по всей территории Украинь, может быть аналогичной современной "электронной декларачии" и помочь разработать стратегию экологически рационального управления сельским хозяйством. Разработанные технологические методы экологического преобразования (вермикультуры, биодинамика и др.) адаптированы к условиям лесостепи Украины и помогут владельцам крестьянских и сельскохозяйственных предприятий реализовывать эту стратегию на практике.

Ключевые слова: агроландиафты, типология сельского хозяйства, конверсия, экологически толерантное земледелие, ландшафтно-экологическое планирование.

Introduction. Reducing agrophytocenosis resistance due to the use of one-species culture and radical change in natural landscapes as well as soils natural fertility decrease caused by humus loss and the need to apply elevated doses of chemically synthesized NPK are among many directions of the negative impact of agriculture on the environment. (Altieri et al., 2011; Bommarco et al., 2012; Caron et al., 2014).

Direct consequence of this negative impact is the fact that since the beginning of the 3rd millennium the world agriculture has left behind industry and transportation, burning fossil fuels, mainly due to plowing of a large array of lands (Csoil $+\mathrm{O}_{2}$ atmosphere $=\mathrm{CO}_{2}$ ) by emissions of carbon monoxide to atmosphere by 10\% (Lun et al., 2016; Foley, 2011).

Analysis of previous studies and publications. It is surprising that this $\mathrm{CO} 2$ source in the atmosphere due to its imperceptibility (it has gradually expanded since the beginning of the "green revolution") is underestimated even in serious monographic studies and practical recommendations that take into account only methane emissions in livestock production (Gracz, 2018; Frank et al., 2015). However, there is another, also "stretched out in time" and, therefore, externally imperceptible impact of agriculture on the landscape. It is loss of soil humus (Semenov, 2013). It is precisely this that represents the greatest danger to the survival of mankind. The deepening of this process is facilitated by the globalization phenomenon through which farmers are forced to pursue profits to "pump" from the soil the last drops of their natural fertility (Almeida et al., 2016; Zhang, 2018). Given that agriculture is the industry close to natural landscapes by the type of substance-energy relations (Bürgi et al., 2017) the search for such forms of its management (specialization) which would not exceed natural opportunities of a particular area is, perhaps, the main task, solu- tion to which should be taken into consideration by the environmentalists (Zuazo et al., 2011; Kiryushin, 2018). Once the world-renowned scientist M.I. Vavilov proposed "to shift agriculture to the north", in particular, to cultivate rye not wheat in a wellmoistened Nechernozem land. Today, the basis of crop production in such countries as Germany, Finland, Sweden and Norway is exactly rye. M.I. Vavilov also believed that wheat should be replaced with sorghum in the southern steppe. Currently, in Italy, Spain and France, the area of sorghum has increased 30-60 times (Rutz et al. 2014). The given example is the evidence of understanding deep relationship between mechanisms of degradation of the landscape's individual components (in particular, soils) and technologies by which it is possible to preserve the ecological situation. In many countries of the world these issues are covered in the landscape legislation which has not been adopted in Ukraine yet (Maksymenko, 2017a; Bulgakov, 2018; Douglas, 2017). These issues are of great importance for ForestSteppe zone where the steppe and forest landscapes diversity does not allow us to explore all data.

How to combine all aspects of ecologicallyfriendly farming in a single methodologically harmonious concept? The answer to this question determines the relevance and practical orientation of our study. To a large extent, the capability of our concept is based on the biodiversity support in agriculture through the division of its specialization (Phalan et al., 2011).

Attempts to "add" agricultural activity to the existing bioclimatic potential has a long history and the method of such research has long-standing traditions (Kostrovickij, 1970). The mentioned problem is integrated because at the level of monitoring it concerns aspects of negative environmental impact of agriculture and at the level of nature use it concerns farming technologies, land management and legal aspects and landscape planning. Indeed, in our 
study, not a separate method or group of methods is considered but the Concept which uses a set of

methods and practical approaches which can be schematically divided into three stages (Fig. 1).

\begin{tabular}{|c|c|}
\hline $\begin{array}{l}\text { environmental } \\
\text { monitoring of } \\
\text { components of } \\
\text { agro-landscape }\end{array}$ & $\begin{array}{l}\text { - methods of pesticides residues bioindication in soils } \\
\text { - instrumental and laboratory methods for evaluating environmental } \\
\text { parameters } \\
\text { - express assessment of environmental impact on soils in certain } \\
\text { agricultural sectors } \\
\text { - geoinformation modeling of agricultural typology } \\
\text { - others }\end{array}$ \\
\hline $\begin{array}{l}\text { environmental } \\
\text { conversion of } \\
\text { agro-landscape }\end{array}$ & $\begin{array}{l}\text { - comprehensive methods of vermontology } \\
\text { - environmental and biological technologies of growing crops } \\
\text { - biodynamic technologies in growing crops } \\
\text { - assessing methods of food industry enterprises impact on } \\
\text { environment }\end{array}$ \\
\hline $\begin{array}{l}\text { landscape - } \\
\text { ecological } \\
\text { planning }\end{array}$ & $\begin{array}{l}\text { inventory stage (investigation of natural conditions and determination } \\
\text { of pollution sources) } \\
\text { identification of internal and external nature conflicts in } \\
\text { agrolandscapes } \\
\text { assessment of sustainability and ecological problems of agro- } \\
\text { landscapes } \\
\text { generalization and forecast of changes in accordance with the target } \\
\text { concept of agro-landscapes territory use } \\
\text { development of optimization measures for ecologically-friendly } \\
\text { agricultural production }\end{array}$ \\
\hline
\end{tabular}

Fig. 1. Algorithm for the implementation of the Concept of environmental protective management in agriculture

The study of the humus balance in soils conducted by us on the territory of Kharkiv region in the mid 80-ies of the last century showed that only 7 out of 430 farms have this positive balance (Sonko, $2018 \mathrm{~b}$ ). Other farms spent this priceless resource of the biosphere at a pace that doubled and even tripled the pace of its accumulation (Fig. 2). This happens when full crop rotations are used after one or even two fallow lands. Today's realities indicate that even with the presence of technologies of five-year rotations three-year rotations are used in agricultural holdings with two fields under cultivated technical crops (Gospodarenko, 2015). The direct consequence of this is the catastrophic loss of land fertility, percentage of humus in which in the last 40 years decreased from $6-7 \%$ in the early 70 's to $2.5-3 \%$ in 2010. Today, according to field surveys and passports analysis of certain fields in the farms of Uman district it is up to $1-1.7 \%$ (Kryvda et al., 2009; Medvedev et al., 2001).

Materials and methods. Approbation of theoretical foundations of the proposed Concept allows to develop a harmonious methodology (Fig. 1) adapted to the conditions of Forest-Steppe areas of
Ukraine and to gradually solve the problems formulated in the relevance of the work.

At the first stage numerous methods of environmental monitoring of agricultural landscape's various components are used, such as methods of biological indication of pesticide residues in soils, instrumental and laboratory methods for evaluating environmental parameters, express estimation of environmental impacts of separate branches of agriculture on soils, geoinformation modeling of agriculture typology(Sonko, 2018b; Sonko, 2018a), etc.

The developed method allows to expressly assess the environmental impact of certain industries on the territory of Cherkasy, Kharkiv, Kirovograd and Poltava regions (Fig. 3).

Results. In particular, within the framework of vermiculture study, the dynamics of the population of earthworm Eisenia foetida was studied depending on the different types of substrates (at the stage of breeding). It is important to note that the obtained population is $100 \%$ aboriginal because it is derived by assimilation from representatives of several local populations (Cherkasy, Kirovograd and Vinnytsia regions). The studies revealed a certain dependence of the dynamics of Eisenia foetida population den- 


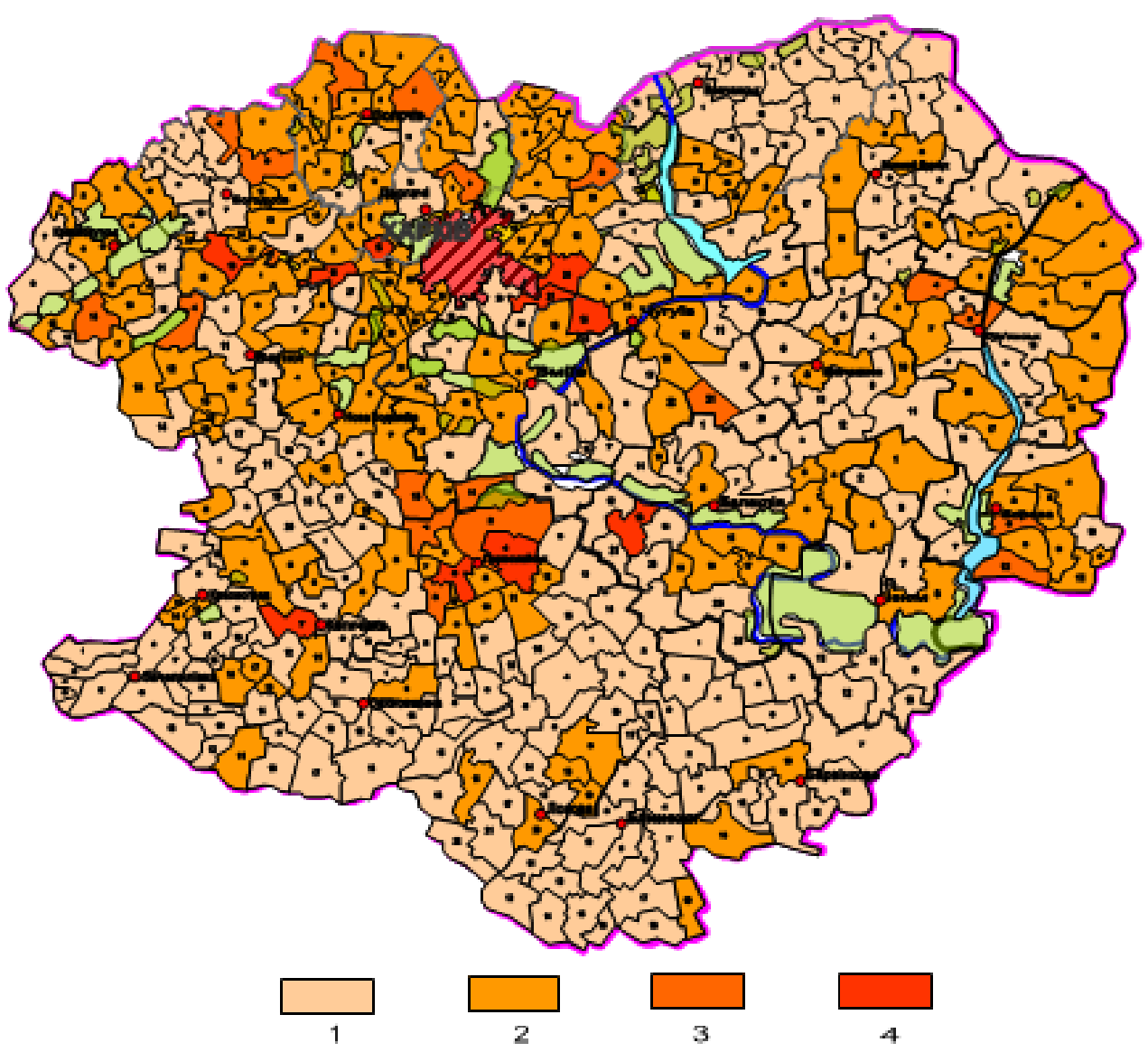

Fig. 2. Environment assessment of agricultural system (Sonko, 2009).

The value of the ecological hazard of agriculture in all farms of Kharkiv region (Kez). 1 - less than 0,$5 ; 2-0,5-0,8 ; 3-0,8-1,0 ; 4$ - more than 1,0

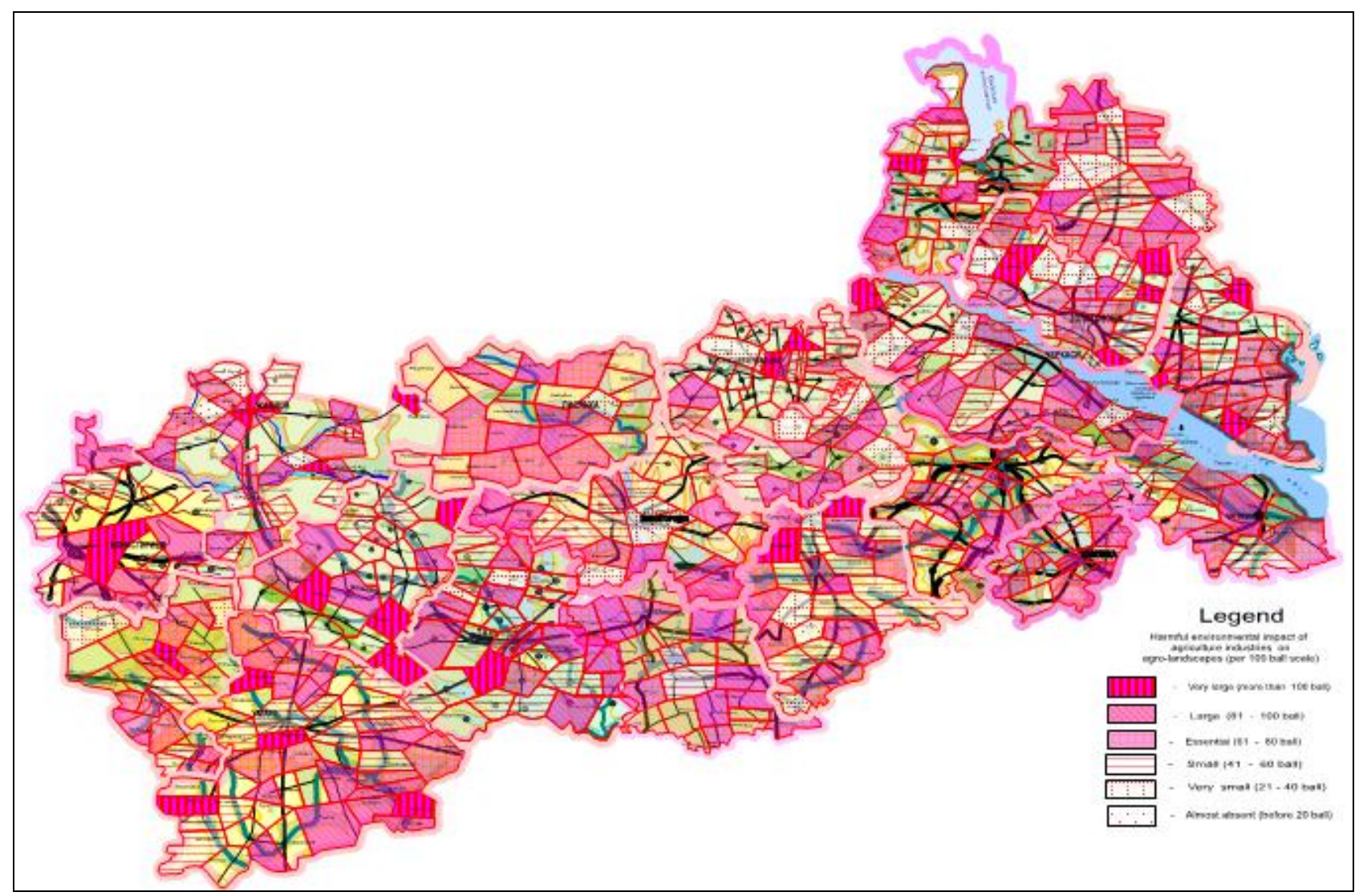

Fig. 3. Assessment of agricultural branches impact on the soil in Cherkasy region (2014-2016) 
sity on the volume of the storing bunker, so the largest increase (47 times) was observed in the storing bunker number 6 . This is explained by the fact that for this variant, at the time of the experiment start for each worm there were $0.0009 \mathrm{~m}^{3}$ of substrate (in the storing bunker number $4-0.0008 \mathrm{~m}^{3}$ ). The dependence is quite natural because distribution of the population is determined by the ecological capacity of the environment which main parameters are space and resources. The volume of substrate at $0.0009 \mathrm{~m}^{3}$ per worm (at the time of population formation) is the most optimal among the selected research options regarding the size and density of Eisenia foetida population. The high population growth indirectly indicates that vermiculture produces more biohumus production than other experimental variants (Chattopadhyay, 2012; Tripathi, 2004). In general, the results of experiments on vermiculture have shown that it is possible to breed Eisenia foetida aboriginal population adapted to local conditions in farms, as well as the possibility of biological utilization of organic matter formed annually in the fields with the help of a worm.

A study was also carried out on the influence of vermiculture product's introduction for agricultural crops (Fig. 4).
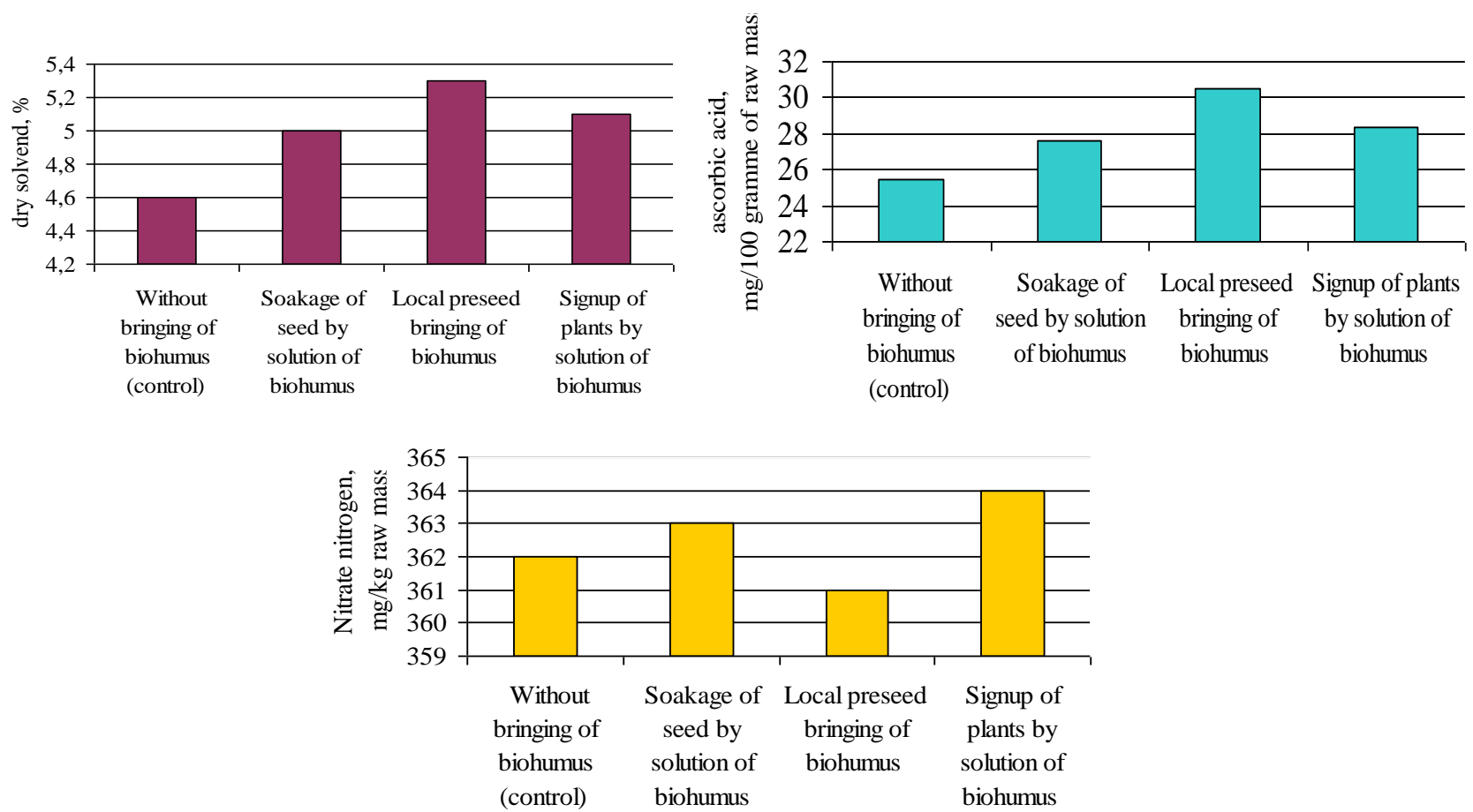

Fig. 4. Biochemical parameters of the sown salad composition depending on the biohumus use methods (average for 2015-2016)

It is has been found that the biohumus use does not affect the level of nitrate contamination of salad and allows obtaining high yield of environmentally safe products. In general, besides the fact that the products were environmentally safe, it was characterized by comparatively high qualitative characteristics in terms of dry matter and vitamin $\mathrm{C}$ content. Interesting results provided a comparison of different ways of introducing biohumus for coriander through biometric and yield indicators (Fig.5).

In fact, one of the main environmental results of experiments with vermiculture products was the high consumer and ecological quality of the final product, in particular, nitrate content in tomatoes (Fig. 6).

According to the results of the experiment, in the variants where local pre-planting of biohumus was made, the highest biometric indicators were recorded for all studied parameters (plant height, fruit weight, fruit diameter and mean number of fruits). In general, the biohumus use increases the average yield of tomatoes by $28.6 \%$. The average nitrate content in the biohumus variants was $9.5 \mathrm{mg} /$ $\mathrm{kg}$ which is ten times less than the MPC indicating that the biohumus is truly environmentally friendly fertilizer. A high biological efficiency (up to 89\%) of biohumus has been registered in relation to the containment of the late blight development.

At the third stage, due to modern methods of landscape-ecological planning (LEP), schemes considering the features of a particular landscape in the organization of various types of agricultural activities have been developed. First of all, it relates to relief and soil which are decisive in the development of environmental optimization measures for environmentally-friendly agricultural production. LEP 


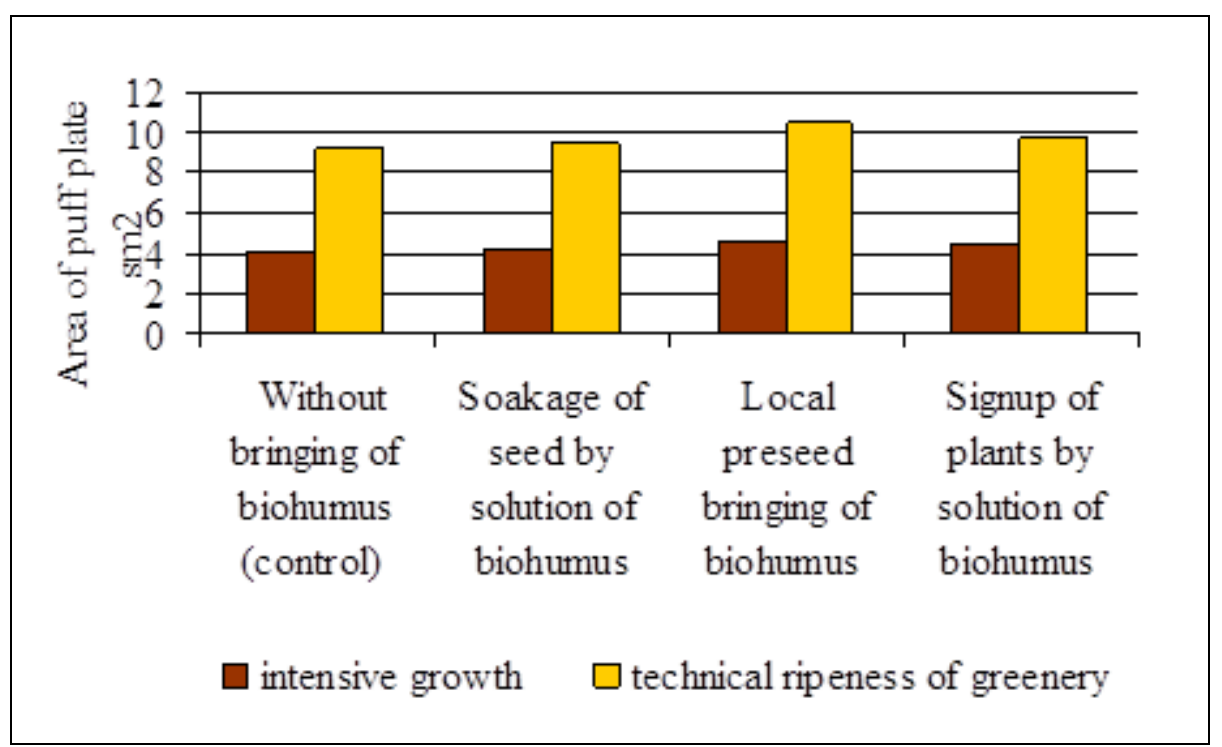

Fig. 5. Biometric indices of coriander depending on the application of biohumus (average for 2015-2016)

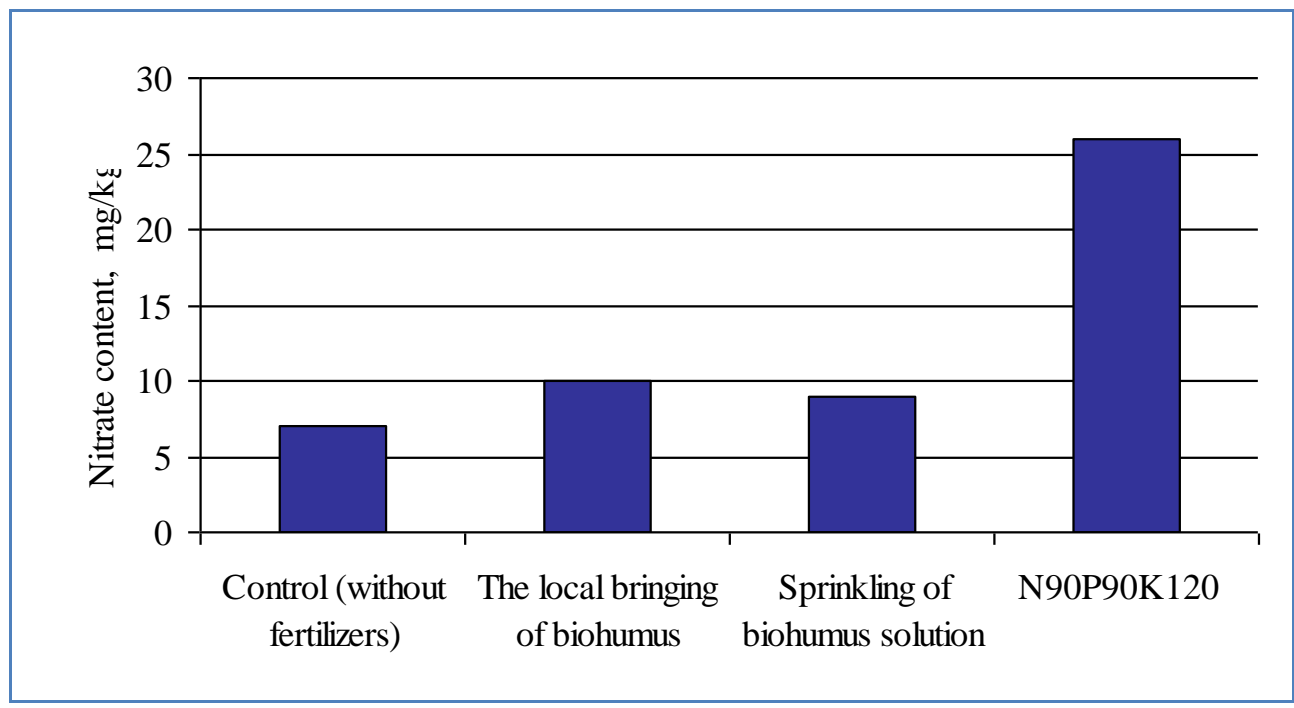

Fig. 6. Content of nitrates in tomatoes, $\mathrm{mg} / \mathrm{kg}$

done on the example of the model territory of Korobochkine Agricultural Enterprise in Chuguiv district of Kharkiv region made it possible to create a series of thematic maps of the most important morphometric indicators based on the digital model of the relief (Fig. 7), such as a hypsometric map, a map of slope expositions and on their basis maps of areas of surface runoff, erosion hazards, geochemical migration of elements and stability of landscapes.

Since the most important natural component of agricultural production is the soil, we add maps of granulometric composition, humus content, acidity, cation exchange capacity, etc. The peculiarity of agricultural landscapes is the almost complete lack of stationary sources of pollution but it is their functioning that causes the emergence of nature management conflicts. Therefore, the following map, which allows taking into account landscape features of ecological agricultural production, contains the boundaries of anthropogenic landscapes, natural and anthropogenic sources of conflicts and zones of possible conflicts of nature management (Fig.7).

The map of conflicts in agricultural landscapes is complemented by a geochemical survey of the territory during which soils and agricultural products were sampled on test sites to determine the content of substances harmful to people and compare them with normative indicators. A continuous geochemical survey is not required in agricultural landscapes since the introduction of fertilizers, herbicides and pesticides is carried out in the same volumes within the entire fields or plots (Maksymenko 2017b).

At the stage of LEP "generalization and forecast of changes in accordance with the target concept of the use of the territory", it is advisable to abandon a typical system of goals and adapt it to constraints imposed by ecologically balanced agricultural production. The main objective of optimizing nature management in agricultural landscapes at the present 


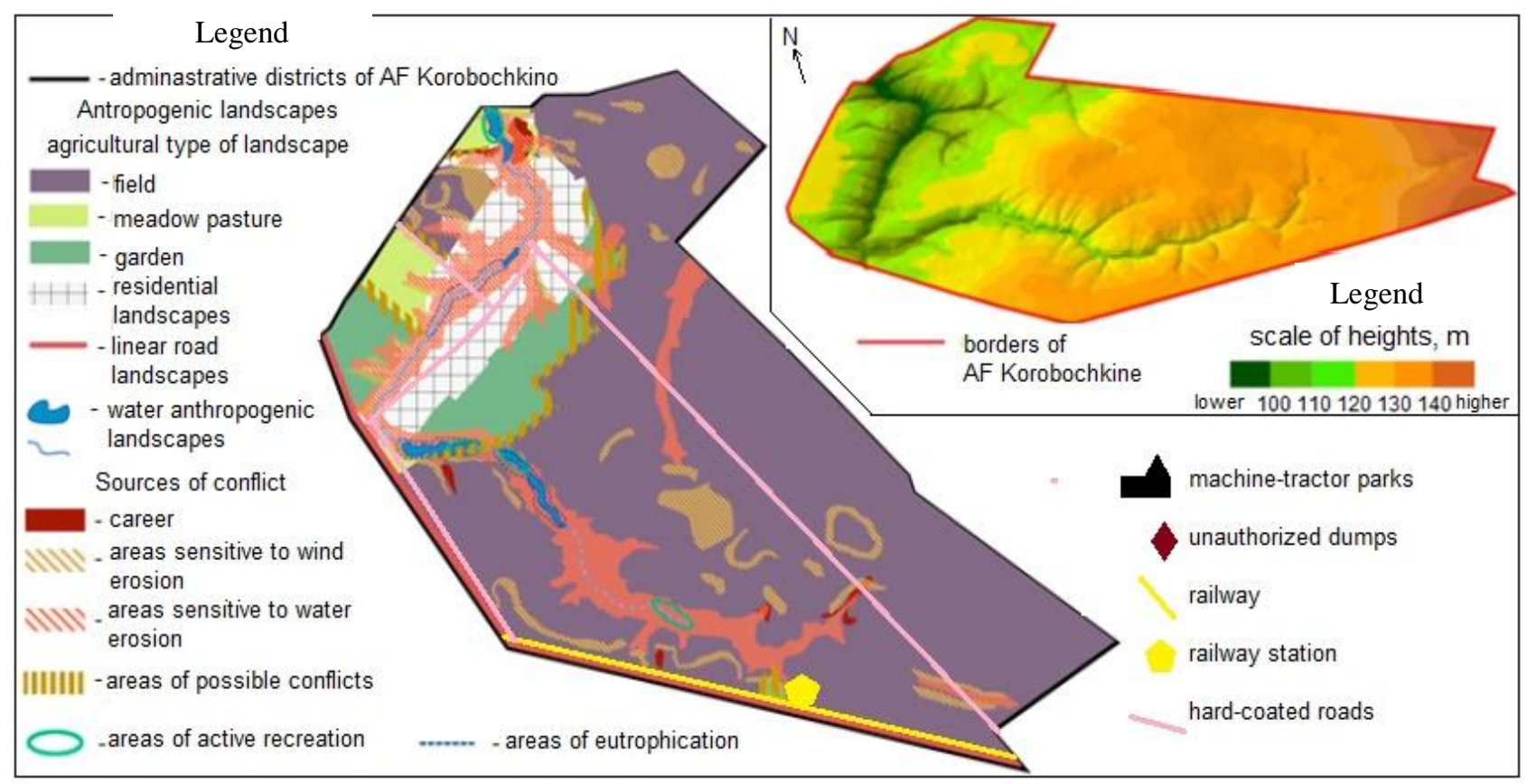

Fig. 7. Conflicts of nature management in AF Korobochkino's anthropogenic landscapes

time is to prevent their degradation which is to simplify the structure and degrade natural properties of the system adversely affecting the vulnerable components, such as soils, biota, surface and groundwater and causing a decrease in the productivity of agricultural ecosystems.

Discussion. Actually, the idea of the correspondence of a certain agricultural field to the natural landscape in which it develops (zoning level) is in the most famous works of V.V. Dokuchaev, M.I. Vavilov, A.S. Yermolov, O.V. Chayanov and O.M. Chelintsev. Taking into account the importance of such studies in the late 1960s, the International Geographical Union conducted a series of studies on the typology of world agriculture for the scientific substantiation of "Green Revolution" technologies.

In these works, the "statistical" and "spatial" basis was a peasant (farming) economy, since it is at the lowest level of the spatial organization of agricultural landscape. The peasant, his family, all the pets and agricultural lands harmonized into the ecosystem where balance of matter was "locked" into a certain natural landscape and whose stability (according to modern terminology) became the subject of inherited care from father to son. At the same time, the mechanism of ensuring such stability, except ownership of land, was the specialization of the peasant economy (Chayanov, 1989).

Since the lower spatial level in nature consists of the smallest units of a landscape organization, such as facies, sub district and district, one can speak of ecological conformity (or inconsistency) of the existing specialization. Considering the fact that these landscape units correspond to the same lowest level in the typology of natural ecosystems, it be- comes clear that the size of the peasant's economy territory should not exceed 10 hectares. Actually, this is exactly the size corresponding to original units of the natural landscape organization and this is the very level of interaction between nature and man and the natural tolerant regulation of such interaction is possible.

The essence of the author's concept of ecologically friendly agriculture is as follows:

1. Untouched or weakly damaged natural landscapes are not only the key to effective and ecologically tolerant agriculture but also the balanced development of the entire state. According to calculations of reputable scientists, natural landscapes must occupy not less than $60 \%$ in each country. According to the Law of Ukraine "On the National Program for the Formation of the National Ecological Network of Ukraine in 2000-2015", “... a state close to the natural one has landscapes in the area of almost 12.7 percent of the territory of the country". Approaching $60 \%$ is a difficult, long and thorny path for which it is necessary to give the highest legal status to the main nature user at the low level of the landscape spatial organization that is the rural community.

2. The rebirth of the Ukrainian village suffering now from the demographic crisis is possible through land relations. Only a free person can work creatively on the land and optimistically look into the future, giving birth to children and bequeathing them their own land and everything that is on it. Here is the main essence and content of a small-scale peasant farm and farm settlement system where farms are analogues of human ecotypes. This system with a high degree of agricultural landscapes variability repeats the spatial structure of the biosphere and 
most harmoniously fits into natural ecosystems. A relatively small area of the peasant economy (up to 10 hectares) gives responsible care for it, in particular, to provide fields of organic matter from its own livestock. Under such conditions, maintenance of natural fertility of soils is a matter of the peasant family, and the subject of inherited care and the "revival" of domestic livestock production is only a matter of time.

3. In order to revive agricultural, spiritual, cultural traditions and, consequently, demographic and environmental stability of rural Ukraine, it is proposed to reform land relations in the following areas:

- Considering that most rural families are forced to survive in present-day modern economic conditions from the land that is in use by the peasant family, one must agree that in the countryside of Ukraine a natural economy has already been formed which in general is not a tragedy but a "tip" determined by the course of events which should be used skillfully;

- Carrying out calculations of peasant families' budgets to specify its size and the degree of merchantability of agricultural statistics (Sonko 2015a);

- According to the results of calculations, allocating production types (specialization) of peasant farms which will be the most objective, since it takes as much as possible the local natural and economic conditions;

- Implementing agricultural zoning of the territory of Ukraine based on the specialization of peasant farms, the study of land use in enterprises of different forms of ownership and data on the natural fertility of lands;

- In each agricultural area, dividing all lands in use into at least 3 groups:

1) Lands of peasant farms which should eventually be granted the right to live on property with the possibility of inheritance (not sale, at least in the first 20-40 years) and a nonprofit, natural economy should be supported. It is in such farms that there will be the greatest demand for the technology of ecological conversion;

2) Lands withdrawn from agricultural circulation due to the destruction of their natural fertility and those to be transferred to the nature reserve fund and, eventually, included in the national ecological network;

3) Lands that have not lost its natural fertility yet and those that are in use by agricultural enterprises of different forms of ownership.

- An appropriate strategy for nature use should be developed for each of the listed groups of lands;

- The main condition of this strategy is diversification of existing agricultural use of land directed on decreasing intensity, in particular a significant reduction of soil-fueled crops in crop rotations, a return to fallow and crop rotation, an increase in land areas under pasture and hayfields as well as rural development of the newest forms of nature management (rural green farmsteads, tourist attractions, green tourism objects, etc).

Conclusions. The 25-year-old domestic experience of farming in market conditions has led to the conclusion that the above examples of ecologically tolerant methods of crop cultivation and livestock production can only be realized under the conditions:

- Confidence of land ownership with the proper support of farmers by the state;

- Prevalence of small and medium-size land holdings in the land use structure.

The experience of conducting an industrial typology of agriculture in the areas of Forest-Steppe zone of Ukraine shows that modern specialization is not only far from optimal but in many cases devastating for soils, in terms of compliance with natural conditions. Hence, the implementation of the agricultural typology with a subsequent assessment of the environmental impact of each type (Sonko, 2018a), first in Forest-Steppe, and, subsequently, throughout the territory of Ukraine can be analogous to the current "electronic declaration" and will help develop a strategy for environmentally sound management of agriculture. The developed technological methods of ecological conversion (vermiculture, biological dynamics, etc.) adapted to the conditions of Forest-Steppe Ukraine will help individual owners of peasant and farm enterprises to implement this strategy in practice.

\section{Jimepamypa}

1. Almeida, C. Typologies and Spatialization of Agricultural Production Systems in Rondônia, Brazil / C. Almeida, M. Mourão, N. Dessay, A. E. Lacques, A. Monteiro, L. Durieux, A.Venturieri, F. Seyler // Linking Land Use, Socioeconomics and Territorial Configuration, 5(2), 2016. - 18 p. doi:10.3390/land5020018.

2. Altieri, M. A., Toledo, V. M. The agroecological revolution in Latin America: rescuing nature, ensuring food sovereignty and empowering peasants. The Journal of Peasant Studies, 38(3), 2011. - P. 587-612. doi: 10.1080/03066150.2011.582947.

3. Bommarco, R., Kleijn, D., Potts, S. G. Ecological intensification: harnessing ecosystem services for food security. Trends in Ecology and Evolution, 28(4), 2012. - P. 230-238. doi: 10.1016/j.tree.2012.10.012.

4. Bulgakov, D. S., Rukhovich, D. I., Shishkonakova, E. The Application of Soil-Agroclimatic Index for Assessing the Agronomic Potential of Arable Lands in the Forest-Steppe Zone of Russia. Eurasian Soil Science, 51, 2018. - 448 p. https://doi.org/10.1134/S1064229318040038. 
5. Bürgi, M., Bieling, C., von Hackwitz, K. Processes and driving forces in changing cultural landscapes across Europe. Landscape Ecology, 32, 2017. - P. 2097. doi.org/10.1007/s10980-017-0513-z.

6. Caron, P., Biénabe, E., Hainzelin, E. Making transition towards ecological intensification of agriculture a reality: the gaps in and the role of scientific knowledge. Current Opinion in Environmental Sustainability, 8. 2014. - P. 4452. doi: 10.1016/j.cosust.2014.08.004.

7. Chattopadhyay, G. N. Use of vermicomposting biotechnology for recycling organic wastes in agriculture. International Journal of Recycling of Organic Waste in Agriculture, 1. 2012. - 8 p. doi: 10.1186/2251-7715-1-8.

8. Чаянов, А. В. Крестьянское хозяйство: избранные труды. / А. В. Чаянов. - Москва : Экономика. 1989 492 c.

9. Douglas, A. Landis Designing agricultural landscapes for biodiversity-based ecosystem services. Basic and Applied Ecology, 18, 2017. P. 1-12. doi.org/10.1016/j.baae.2016.07.005

10. Erhart, E., Hartl, W.. Soil Protection Through Organic Farming: A Review, in: Organic Farming, Pest Control and Remediation of Soil Pollutants, Lichtfouse, E. (Eds.) Sustainable Agriculture Reviews, 1. 2009. - P. 1-3. doi: 10.1007/978-1-4020-9654-9_11.

11. Solutions for a cultivated planet. / J. A. Foley, N. Ramankutty, K. A. Brauman. - Nature, 2011. - P. 337-342. doi: 10.1038/nature10452.

12. Frank, S., Schmid, F., Havlik, P. The dynamic soil organic carbon mitigation potential of European cropland. Global Environmental Change, 35, 2015. P. 269-278. DOI: 10.1016/j.gloenvcha.2015.08.004.

13. Господаренко, Г. Н. Содержание гумуса в черноземе оподзоленном после длителного применения удобрений в полевом севообороте / Г. Н. Господаренко, И. В. Прокопчук, // Почвоведение и агрохимия, 2(55), 2015. - С. $102-107$.

14. Gracz, W. Analysis of the Potential of Methane Emission and Energy Power from Excrement of Livestock in Poland I W Gracz, W. Golimowski, K. Butlewski. In: Mudryk, K., Werle, S. (eds) Renewable Energy Sources: Engineering, Technology, Innovation. Springer Proceedings in Energy. 2018. - P. 139-149 . doi.org/10.1007/978-3-319-72371$6 \_14$.

15. Kiryushin, V. I. (2018). Ecological Functions of Landscapes. Eurasian Soil Science. $51,14$. https://doi.org/10.1134/S106422931801009X.

16. Kostrovickij, E. Basic principles and methods of typology of world agroindustry, Известия АН СССР. Серия Географическая, 6, 1970. - P. 162-168.

17. Баланс елементів живлення і гумусу в землеробстві Черкаської області за 2008 рік. / Ю. І.Кривда, В. Г. Демиденко, Н. М. Терещенко. - Холоднянське, 2009.

18. Lun, F. Estimating cropland carbon mitigation potentials in China affected by three improved cropland practices. / F. Lun, J. G Canadell, L. He // Journal of Mountain Science, 13(10), 2016. - P. 1840-1854. doi: 10.1007/s11629015-3813-2.

19. Maksymenko, N., Soils Assessment in Natural and Anthropogenic Landscapes for Environmental. / N. Maksymenko, A. Kleshch, G. Titenko, A. Shumilova, N. Cherkashyna // Imperial Journal of Interdisciplinary Research, 3, 6. 2017. - P. 776-781.

20. Максименко, Н. В. Напрямки оптимізації природокористування в інвайронментальному менеджменті територій локального рівня організачї довкілля. // Н. В. Максименко // Bulletin of the University of Dnipro, Geology, geography, 25(2), 2017. - C. 81-88. doi: 10.15421/111722.

21. Медведєв, В. В. Стан родючості грунтів Украӥни та прогноз його змін за умов сучасного землеробства / B. В. Медведєв, В. В.Лісовий, Харків: Штріх. - 2001.- 100 c.

22. Reconciling food production and biodiversity conservation: land sharing and land sparing compared / B. Phalan, M. Onial, A. Balmford, R. E. Green // Science, 333(6047), 2011. - P. 1289-1291. doi: 10.1126/science.1208742.

23. Rutz, D. Socio-Economic Impacts of Sweet Sorghum Value Chains in Temperate and Tropical Regions / D. Rutz, R. Janssen, C. Khawaja // in: Socio-Economic Impacts of Bioenergy Production. 2014. - 290 p. doi: 10.1007/978-3319-0ю829-2_7.

24. Semenov, V. M. Humification and nonhumification pathways of the organic matter stabilization in soil: A review. I V. M. Semenov, A. S. Tulina, N. A Semenova. Eurasian Soil Science, 46, 2013. - 355 p. doi: 10.1134/S106422931304011X.

25. Sonko, S. P. Express assessment of environmental impact of agriculture technologies on the soils of Cherkasy Oblast. Ukrainian Journal of Ecology, 8(1), 2018. - C. 451-459. doi:10.15421/2017_235.

26. Сонько, С. П. Сільськогосподарське районування Харківскої області: географічна проблема - екологічні наслідки / Bulletin of the University of Dnipro. Geology, geography, 26(1), 2018. - C. 165-176. doi: 10.15421/111818.

27. Tripathi, G., Bhardwaj, P. Comparative studies on biomass production, life cycles and composting efficiency of Eisenia fetida (Savigny) and Lampito mauritii (Kinberg). Bioresource Technology, 92, 2004. - P. 275-278. doi: 10.1186/2251-7715-1-15.

28. Зеркалов, I. I. Енергозбереження в Україні. Київ : Основа. 2012. - 582 с.

29. Zhang, X., Zhu, A., Yang, W. Relationships between soil macroaggregation and humic carbon in a sandy loam soil following conservation tillag // Journal of Soils and Sediments, 18 (3). 2018. P. 688-696. doi.org/10.1007/s11368017-1809-y. 
30. Sustainable Land Use and Agricultural Soil /V. H. D. Zuazo, C. R. R. Pleguezuelo, D. Flanagan. in: Lichtfouse, E. (Eds) Alternative Farming Systems, Biotechnology, Drought Stress and Ecological Fertilisation, Sustainable Agriculture Reviews, 6. 2011. - P. 107-192. doi: 10.1007/978-94-007-0186-1_5.

*Всі автори брали участь у виконанні НДР «Моделювання і прогнозування змін природних і природноантропогенних комплексів для цілей ландшафтного планування», № державної реєстрації $0112 \mathrm{U} 007571$

UDC: 502.52(292.485):631.153.3(477)

\section{Sergiy Sonko,}

Doctor of Sciences (Geography), Professor,

Department of ecology and safety of vital functions, Uman National University of Horticulture, Instytutska str., 1, Uman, Cherkasy region, 20300, Ukraine, e-mail: sp.sonko@gmail.com, https://orcid.org/0000-0002-7080-9564;

\section{Nadiya Maksymenko,}

$\mathrm{PhD}$ (Geography), Associate Professor, Department of Monitoring and Nature Management,

V. N. Karazin Kharkiv National University, Svobody sq., 6, Kharkiv, 61022, Ukraine, e-mail: nadezdav08@gmail.com, https://orcid.org/0000-0002-7921-9990;

\section{Vilina Peresadko,}

Doctor of Sciences (Geography), Professor,

Department of Physical Geography and Cartography, V. N. Karazin Kharkiv National University, Svobody sq., 4, Kharkiv, 61022, Ukraine, e-mail: vilinaperesadko@ gmail.com, https://orcid.org/0000-0002-2439-2788;

\section{Iryna Sukhanova,}

$\mathrm{PhD}$ (Biology), Associate Professor, Department of ecology and safety of vital functions, Uman National University of Horticulture, e-mail: sukhanoffaira@gmail.com,

\section{Olga Vasylenko,}

$\mathrm{PhD}$ (Agrarian Sciences), Associate Professor, Department of ecology and safety of vital functions, Uman National University of Horticulture, e-mail: vsolga05@gmail.com,

Olga Nikitina,

$\mathrm{PhD}$ (Agrarian Sciences), Associate Professor, Department of ecology and safety of vital functions, Uman National University of Horticulture, e-mail: sp.sonko@ gmail.com

\section{CONCEPT OF ENVIRONMENTALLY PROTECTIVE FARMING FOR THE FOREST-STEPPE ZONE}

Formulation of the problem. Taking into account that agriculture is the branch closest to natural landscapes on the type of material-energy relations, the main task of agroecology is search of management forms (specialization) that would not exceed natural capacity of a specific territory. The best management of the nature use at the agro-landscape level can be implemented only in case of complete confidence in the land property, as well as in the presence of small areas from farmers that would correspond to the grassroots levels of the landscape structure. It is under this condition that the farmer can be taken care of with the support of the natural fertility of the land. In addition, the determined ownership of land (not lease) will force the peasant to form specialization in order to work as self-sustaining as possible. Under such conditions, the revival of domestic livestock, as a guarantee of the maintenance of natural fertility of soils is just a matter of time.

The purpose of the article. To develop the concept of environmentally protective farming for the forest-steppe zone.

Methods. Approbation of the theoretical foundations of the proposed Concept allowed to develop a harmonious methodology: at the first stage, numerous methods of environmental monitoring of various components in the agricultural landscape are used, such as methods of biological indication of pesticide residues in soils, instrumental and laboratory methods for evaluating environmental parameters, express estimation of environmental impacts on soils of separate branches of agriculture, GIS-modeling of agricultural typology and landscape - ecological planning; at the second stage, comprehensive methods on vermiculture study, ecological and biological technologies of agricultural crops cultivation have been developed, as well as biody- 
namic technologies in growing crops and methods of assessing the impact of food industry enterprises on the state of the environment.

Results. The authors' concept, adapted to the conditions of the UA forest-steppe area, consists of serial blocks of research: "Ecological monitoring of agro-landscape components "; "Ecological conversion of agrolandscapes"; "Landscape-ecological planning". The main goal of this Concept is not to focus on large agroholdings, but on farmer farmers.

The experience of conducting an industrial typology of agriculture in the regions of the UA foreststeppe zone suggests that modern specialization is not only far from optimal in terms of compliance with natural conditions but also in many cases is devastating to soils. Therefore, the assessment of the environmental impact of each type of agriculture, first in the forest-steppe, and, subsequently, throughout the territory of Ukraine, can be analogous to the modern "electronic declaration" and will help develop a strategy for environmentally sound management of agriculture. The developed technological methods of ecological conversion (vermiculture, biodynamics, etc.) are adapted to the conditions of the forest-steppe of Ukraine, and will help owners of peasant and farm enterprises implement this strategy in practice.

Keywords: agro-landscape, typology of agriculture, conversion, ecologically tolerant farming, landscape-ecological planning.

\section{References}

1. Almeida, C., Mourão, M., Dessay N., Lacques, A. E., Monteiro, A., Durieux, L., Venturieri, A., Seyler, F. (2016). Typologies and Spatialization of Agricultural Production Systems in Rondônia, Brazil: Linking Land Use, Socioeconomics and Territorial Configuration, 5(2), 18. doi:10.3390/land5020018.

2. Altieri, M. A., Toledo, V. M. (2011). The agroecological revolution in Latin America: rescuing nature, ensuring food sovereignty and empowering peasants. The Journal of Peasant Studies, 38(3), 587-612. doi: 10.1080/03066150.2011.582947.

3. Bommarco, R., Kleijn, D., Potts, S. G. (2012). Ecological intensification: harnessing ecosystem services for food security. Trends in Ecology and Evolution, 28(4), 230-238. doi: 10.1016/j.tree.2012.10.012.

4. Bulgakov, D. S., Rukhovich, D. I., Shishkonakova, E. (2018). The Application of Soil-Agroclimatic Index for Assessing the Agronomic Potential of Arable Lands in the Forest-Steppe Zone of Russia. Eurasian Soil Science, 51, 448. doi.org/10.1134/S1064229318040038.

5. Bürgi, M., Bieling, C., von Hackwitz, K. (2017). Processes and driving forces in changing cultural landscapes across Europe. Landscape Ecology, 32, 2097. doi.org/10.1007/s10980-017-0513-z.

6. Caron, P., Biénabe, E., Hainzelin, E. (2014). Making transition towards ecological intensification of agriculture a reality: the gaps in and the role of scientific knowledge. Current Opinion in Environmental Sustainability, 8, 44-52. doi: 10.1016/j.cosust.2014.08.004.

7. Chattopadhyay, G. N. (2012). Use of vermicomposting biotechnology for recycling organic wastes in agriculture. International Journal of Recycling of Organic Waste in Agriculture, 1, 8. doi: 10.1186/2251-7715-1-8.

8. Chayanov, A. V. (1989). Peasant Farm: Selected Works, Moscow, Economics (in Russian).

9. Douglas, A. (2017). Landis Designing agricultural landscapes for biodiversity-based ecosystem services. Basic and Applied Ecology, 18, 1-12. doi.org/10.1016/j.baae.2016.07.005

10. Erhart, E., Hartl, W. (2009). Soil Protection Through Organic Farming: A Review, in: Organic Farming, Pest Control and Remediation of Soil Pollutants, Lichtfouse, E. (Eds.) Sustainable Agriculture Reviews, 1. doi: 10.1007/9781-4020-9654-9_11.

11. Foley, J. A., Ramankutty, N., Brauman, K. A., Cassidy, E. S., Gerber, J. S., Johnston, M., Mueller, N. D., O’Connell, C., Ray, D. K,, West, P. C., Balzer, C., Bennett, E. M., Carpenter, S. R., Hill, J., Monfreda, C., Polasky, S., Rockström, J., Sheehan, J., Siebert, S., Tilman, D., Zaks, D. P. (2011). Solutions for a cultivated planet. Nature, 478, 337-342. doi: 10.1038/nature10452.

12. Frank, S., Schmid, F., Havlik, P. (2015). The dynamic soil organic carbon mitigation potential of European cropland. Global Environmental Change, 35, 269-278. doi: 10.1016/j.gloenvcha.2015.08.004.

13. Gospodarenko, G. N., Prokopchuk, I. V. (2015). Humus content in chernozem after prolonged use of fertilizers in field crop rotation. Soil science and agrochemicals, 2 (55), 102-107 (in Russian).

14. Gracz, W., Golimowski, W., Butlewski, K., Marcinkowski, D. (2018). Analysis of the Potential of Methane Emission and Energy Power from Excrement of Livestock in Poland. In: Mudryk, K., Werle, S. (eds) Renewable Energy Sources: Engineering, Technology, Innovation. Springer Proceedings in Energy. doi.org/10.1007/978-3-319-72371$6 \_14$.

15. Kiryushin, V. I. (2018). Ecological Functions of Landscapes. Eurasian Soil Science. 51, 14. doi: 10.1134/S106422931801009X.

16. Kostrovickij, E. (1970). Basic principles and methods of typology of world agroindustry, Izvestija AN SSSR. Serija geograficheskaja, 6, 162-168.

17. Kryvda, Yu. I., Demidenko, V. G., Tereshchenko, N. M., Kovalenko, T. V., Kalinichenko, O. M., Ivasikov, L. P., Shaptalenko, A. P. (2009). Balance of nutrients and humus elements in Cherkassy region agriculture in 2008, Kholodnianske, Ukraine (in Ukrainian). 
18. Lun, F., Canadell, J. G., He, L. (2016). Estimating cropland carbon mitigation potentials in China affected by three improved cropland practices. Journal of Mountain Science, 13(10), 1840-1854doi.org/10.1007/s11629-015-3813-2.

19. Maksymenko, N., Kleshch, A., Titenko, G., Shumilova, A., Cherkashyna, N. (2017 b). Soils Assessment in Natural and Anthropogenic Landscapes for Environmental. Imperial Journal of Interdisciplinary Research, 3, 6, 776-781.

20. Maksymenko, N. (2017 a). Napriamky optymizatsii pryrodokorystuvannia $v$ invaironmentalnomu menedzhmenti terytorii lokalnoho rivnia orhanizatsii dovkillia [Directions of optimization of nature management in the invariable management of territories of the local level of environmental organization]. Bulletin of the University of Dnipro, Geology, geography, 25(2), 81-88. doi: 10.15421/111722.

21. Medvedev, V. V., Lisovy, V. V. (2001). State of soil fertility in Ukraine and forecast of its changes in modern agriculture, Strih, Kharkiv (in Ukrainian).

22. Phalan, B., Onial, M., Balmford, A., Green, R. E. (2011). Reconciling food production and biodiversity conservation: land sharing and land sparing compared. Science, 333(6047), 1289-1291. doi: 10.1126/science.1208742.

23. Rutz, D., Janssen, R., Khawaja, C. (2014). Socio-Economic Impacts of Sweet Sorghum Value Chains in Temperate and Tropical Regions, in: Socio-Economic Impacts of Bioenergy Production. DOI: 10.1007/978-3-319-0ю829-2_7.

24. Semenov, V. M., Tulina, A. S., Semenova, N. A. (2013). Humification and nonhumification pathways of the organic matter stabilization in soil: A review. Eurasian Soil Science, 46, 355. doi.org/10.1134/S106422931304011X.

25. Sonko, S. P. (2018 a). Express assessment of environmental impact of agriculture technologies on the soils of Cherkasy Oblast. Ukrainian Journal of Ecology, 8(1), 451-459. doi:10.15421/2017_235.

26. Son'ko, S. P. (2018 b). Silskohospodarske raionuvannia Kharkivskoi oblasti heohrafichna problema - ekolohichni naslidky [Geographical regionalization of the Kharkiv region is a geographical problem - the environmental consequences]. Bulletin of the University of Dnipro. Geology, geography, 26(1), 165-176. doi: 10.15421/111818.

27. Tripathi, G., Bhardwaj, P. (2004). Comparative studies on biomass production, life cycles and composting efficiency of Eisenia fetida (Savigny) and Lampito mauritii(Kinberg). Bioresource Technology, 92, $275-278$. doi: 10.1186/2251-7715-1-15.

28. Zerkalov, D. V. (2012). Energy saving in Ukraine. Osnova, Kyiv. ISBN 978-966-699-655-1 (in Ukrainian).

29. Zhang, X., Zhu, A., Yang, W. (2018). Relationships between soil macroaggregation and humic carbon in a sandy loam soil following conservation tillage. Journal of Soils and Sediments, 18: 688. doi.org/10.1007/s11368-017$1809-y$.

30.Zuazo, V. H. D., Pleguezuelo, C. R. R., Flanagan, D., Tejero, I. G., Fernández, J. L. M. (2011). Sustainable Land Use and Agricultural Soil, in: Lichtfouse, E. (Eds) Alternative Farming Systems, Biotechnology, Drought Stress and Ecological Fertilisation, Sustainable Agriculture Reviews, 6. doi: 10.1007/978-94-007-0186-1_5. 